\title{
Three Steps Mixed (Fire Tube-Water Tube) Vertical Boiler to Optimize Thermal Performance
}

\author{
Duilio Aguilar Vizcarra $^{1}$, Doris Esenarro ${ }^{2}$ (D) and Ciro Rodriguez ${ }^{3, *(D)}$ \\ 1 Department of Mechanical Engineering, Universidad Nacional de Ingeniería UNI, Lima 25, Peru; \\ aguilav15@gmail.com \\ 2 Department of Environmental Engineering, Universidad Nacional Federico Villarreal UNFV, Lima 32, Peru; \\ desenarro@unfv.edu.pe \\ 3 Department of Software Engineering, Universidad Nacional Mayor de San Marcos UNMSM, Lima 01, Peru \\ * Correspondence: crodriguezro@unmsm.edu.pe
}

Citation: Aguilar Vizcarra, D.;

Esenarro, D.; Rodriguez, C. Three Steps Mixed (Fire Tube-Water Tube) Vertical Boiler to Optimize Thermal Performance. Fluids 2021, 6, 93 . https://doi.org/10.3390/fluids6030093

Academic Editors: Carlos A. Nieto De Castro and Faik Hamad

Received: 1 January 2021

Accepted: 20 February 2021

Published: 25 February 2021

Publisher's Note: MDPI stays neutral with regard to jurisdictional claims in published maps and institutional affiliations.

Copyright: (c) 2021 by the authors. Licensee MDPI, Basel, Switzerland This article is an open access article distributed under the terms and conditions of the Creative Commons Attribution (CC BY) license (https:// creativecommons.org/licenses/by/ $4.0 /)$

\begin{abstract}
The research aims to design and construct a new mixed vertical boiler (fire tube - water tube) with three gas passes. The strength of this technological innovation is in the best use of the thermic transmission receiving fluid (hot water, steam, thermal oil), this due to its multipurpose function of three steps using alternative fuels (Diesel, Liquid Petroleum Gas LPG, natural gas), by improving the thermal efficiency of the boiler its temperature is reduced with gases at low temperatures, which in turn also reduce environmental pollution. The methodology focuses on calculating the transfer area with the calculation method that will allow dimensioning the boiler, considering the calculation of losses and the fluid speed, with two defined procedures, the first for fire tube and water tube boilers. And another alternative. The results obtained allowed optimizing the thermal efficiency level, achieving very significant thermal efficiency results: With LPG 92.4\% for hot water and $92.42 \%$ to generate steam in the same way with natural gas $90.25 \%$ for hot water and $90.24 \%$ to generate steam as well with Diesel $2 ; 89.21 \%$ for hot water and $89.31 \%$ to generate steam.
\end{abstract}

Keywords: three-step mixed boiler; fire-water tube boiler; steam; fluid; fuel; diesel; natural gas; Liquid Petroleum Gas (LPG)

\section{Introduction}

Through the times and the investigations carried out, after coal, the discovery of fossil hydrocarbons, a type of liquid fuel that could be refined, allowed the industry to achieve a great technological take-off and with it its massive consumption [1].

Later on, the explorations and investigations managed to value the natural gas and derivatives of the Liquid Petroleum Gas (LPG) and various mixed gases. The massive consumption of hydrocarbon fossil fuels in its diverse forms achieved through time, that the use of chemical energy contained in these, can be used in different types of thermal machines and that through combustion can transform this energy into work in the axis of a device or provide heat for industrial processes of various types.

In this second type of machines are the boilers consuming fossil fuels and gaseous, which are the equipment of great applicability in the industry worldwide, with the fundamental objective of transforming the chemical energy contained in the fuels into thermal energy through combustion and transferring it to water to produce hot water, steam or thermal oil, which are used as an energy source to carry out various industrial processes [2].

To achieve a high use in the boilers' operation, it is necessary to have adequate designs and other permanent research characteristics to search for better results that allow operating with greater thermal efficiency.

The boilers, according to the arrangement of the tubes, are classified in a water tube, or water tubes and pyrotubular or fire-tube, each type of them according to the precision of the design and construction a value of its thermal efficiency that affects the fuel consumption 
and therefore emits to the environment combustion gases at a certain temperature, Both types of boilers have specific applications that in the case of water tube boilers are used to generate high amounts of steam at high pressures [3], for example in steam power plants and pyrotubular boilers are used in thermal processes that do not require higher pressures and therefore saturated steam temperatures that are not very high.

Pyrotubular boilers are generally constructed horizontally and can be classified by the combustion gases' path through the transfer surface in one, two, three, and four gas passes. Vertical type boilers are also constructed, and generally, the number of passes can be one or two, with low values of thermal efficiency and evacuation of gases to the environment with high temperatures; also, they can be of three passes or routes, being able to be constructed all the boilers with controls of automatic operation and its constructive form is in a single block or to the interior of a cylindrical tank is horizontal or vertical, with the difficulties of times and costs of maintenance that it implies [4].

The intensive use of the boilers to generate steam or hot water and thermal oil for the diverse industrial processes implies a significant consumption of fuels. Therefore, its incidence in the cost of operation is a function of the thermal efficiency of the boiler, of there the necessity to construct a boiler previously dimensioned, that allows to surpass the limitations of the type of design, being this one that looks for to take advantage of the heat of combustion given by the product gases of the combustion that, at the same time when emitting gases to the environment to smaller temperature, is friendlier with this one.

Considering that the level of thermal efficiency has a direct incidence in the operation costs, the increase of the efficiency will mean an economy in the fuel cost and, therefore, a more significant economic benefit. It is necessary to optimize this value [5].

What was expressed in the previous paragraphs is verified with the research formulated in [6] where the author implements modifications to the design of a coal-water tube boiler, whose efficiencies are usually low values without economizer and using economizer can reach values of $89 \%$, and results of their tests exceed $90 \%$ modifying the design with fuel economy and emissions reduction [6].

In the same way, in a systematized application of neural networks, from the room temperature as input data and with a seven-day prediction, [6] achieves efficiencies close to $92 \%$ in the water-tube boilers of a coal-fired power plant, with a reduction of emissions and temperature [7].

The possibility of using alternating liquid and gaseous fuels will not allow stopping its production process for the scarcity of these and the possibility of generating alternatively steam, hot water or thermal oil, allows that the investment to carry out is smaller, for having multipurpose equipment; such as reducing the cost and time of maintenance when constructing a boiler that allows separating the combustion chamber and water chamber, also it is important to consider the economy of space since the economy of investment in equipment is solved with the use of multipurpose equipment.

Heat generating equipment must offer economy in fuel consumption, and this is intimately linked to the thermal efficiency of the equipment [8], which is reflected in the temperature of exit of combustion gases to the environment, its relationship with the greenhouse effect, and environmental pollution.

By solving these limitations with a prototype that allows the use of the same equipment for the alternative use of thermal fluids, alternative fuels, and better use of the heat of combustion that will be reflected in greater thermal efficiency, for which it will be necessary to dimension and build a boiler that constitutes a technological innovation with the following characteristics:

1. Three-pass boiler allows better use of the combustion heat from the exhaust gases and obtains a higher thermal efficiency.

2. Multipurpose because it allows better use of the unit to be built from two points of view:

(1) The possibility of using alternative fuels such as diesel, natural gas, and LPG 
(2) The use of the heat of combustion in heat-carrying fluids to produce hot water, steam, or thermal oil can be done in different units or the same unit.

3. The boiler's construction in two subsystems will allow the maintenance activities to be carried out more objectively and reduce the cost and frequency of maintenance.

This is a new type of boiler design and construction, as it combines in its design and construction the concept of a fire tube boiler and a water tube boiler as a technological innovation [9-13]. Below are shown Figures 1-3 to establish the differences of vertical boilers with one and two gas passes in versions of hot water and steam, whose heat utilization is clearly explained to a boiler with three gas passes [10]. Table 1 shows the comparison.

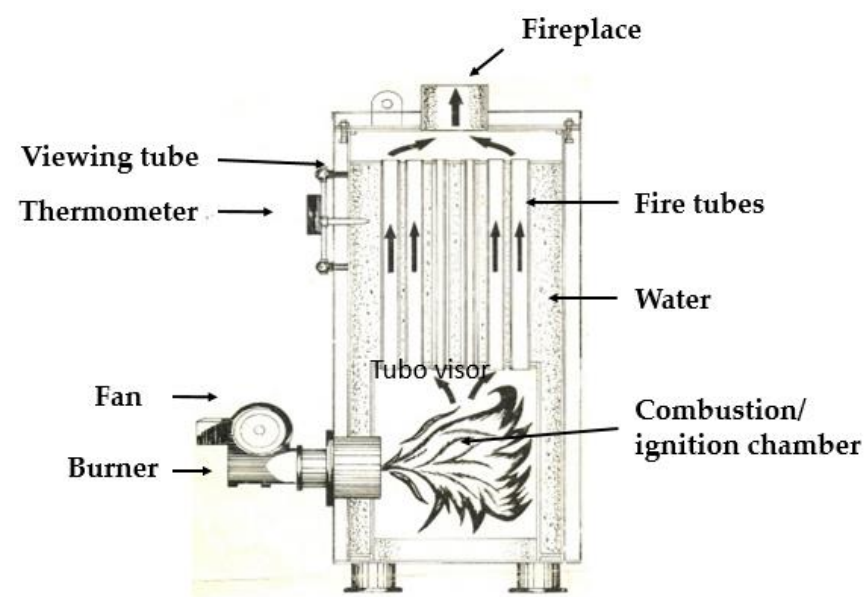

Figure 1. Vertical single-pass hot water boiler. It is built due to lack of space; it is inefficient, it has a single gas passage whose temperature emitted into the environment is very high, around $500{ }^{\circ} \mathrm{C}$, the water is only stored around the fire tubes on the side of the combustion chamber. Eventually, there may be water, but it is usually thermally insulated.

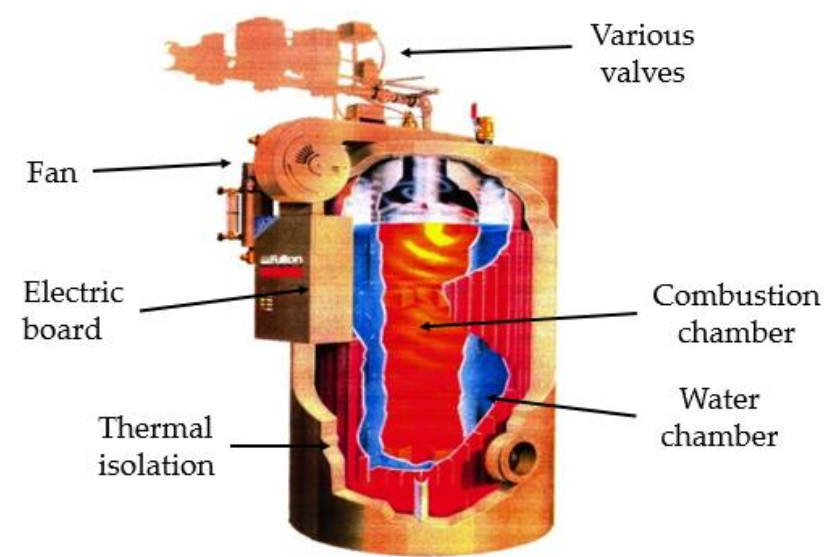

Figure 2. Vertical steam boiler two gas passes. It is a two-pass gas boiler; the first step is the combustion chamber, where the gases descend vertically, touching the bottom externally to the water as they rise to exit through the chimney. The second is distributed radially and rises externally to the water chamber to exit through the chimney. 


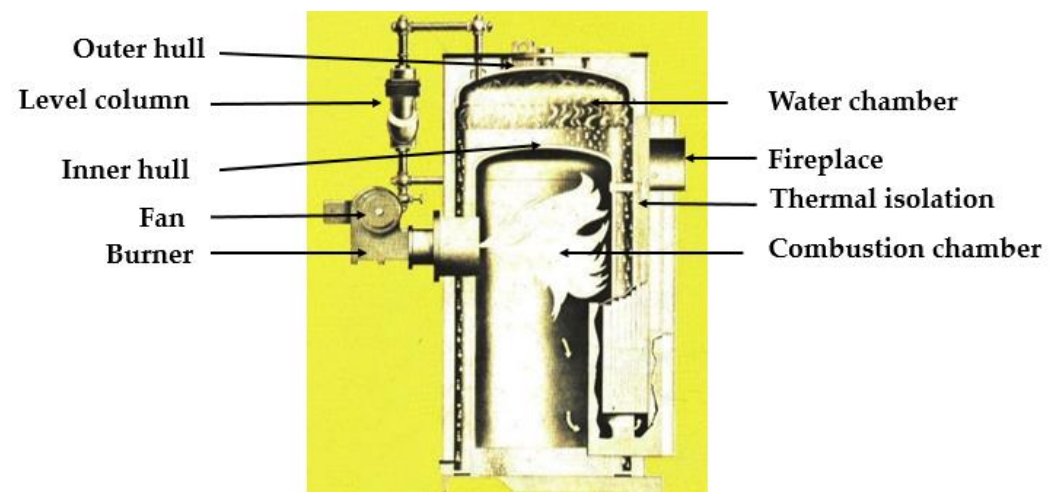

Figure 3. Vertical, tubeless boiler with two flue gas paths. Two-pass boiler without tubes. The first route is the passage of gases through the combustion chamber; the gases descend to the bottom and surround the water chamber and rise vertically to exit through the chimney.

Table 1. Comparison of the different boilers.

\begin{tabular}{cccc}
\hline $\begin{array}{c}\text { Pass Flue Gas Vertical Hot } \\
\text { Water Boiler }\end{array}$ & $\begin{array}{c}\text { Pass Two Flue Gas } \\
\text { Vertical Boiler }\end{array}$ & $\begin{array}{c}\text { Two-Pass Flue Gas } \\
\text { Tubeless Boiler }\end{array}$ & Three-Pass Flue Gas Boiler \\
\hline $\begin{array}{c}\text { Combustion gases in a single } \\
\text { cycle emit very hot gases } \\
\text { around } 500^{\circ} \mathrm{C} \text {, it was worked } \\
\text { with diesel II }\end{array}$ & $\begin{array}{c}\text { Combustion gases in two gas } \\
\text { steps emit gases into the } \\
\text { environment around } 250 \text { and } \\
300^{\circ} \mathrm{C} \text {; it was worked with } \\
\text { diesel fuel II }\end{array}$ & $\begin{array}{c}\text { Combustion gases in two gas } \\
\text { steps emit gases into the } \\
\text { environment around } 300^{\circ} \mathrm{C} \text {; it } \\
\text { was worked with diesel oil II }\end{array}$ & $\begin{array}{c}\text { In three gas steps, combustion } \\
\text { gases emit gases into the } \\
\text { environment around } \\
185 \text { degrees Celsius; it was } \\
\text { worked with diesel oil. }\end{array}$ \\
\hline
\end{tabular}

Wejkowski [10] presented technical-economic analysis results using a system in which the number of fins in a bank of tubes of a boiler called TFT (Triple Fined Tubes) triples and compares three arrangements alternatives: A, B, C, as showed in Table 2.

Table 2. Technical analysis comparing three arrangement alternatives.

\begin{tabular}{cccc}
\hline & A & B & C \\
\hline Boiler efficiency \% & 89.57 & 90.01 & 90.58 \\
Fuel comsumption $(\mathrm{Kg} / \mathrm{h})$ & 19085.9 & 18938.4 & 18864.6 \\
Fuel comsumption $(\mathrm{Kg} / \mathrm{s})$ & 5.302 & 5.092 & 5.240 \\
\hline
\end{tabular}

Strušnik et al. [6] proposed the development of artificial neural network (ANN) models using real data from a Slovenian power plant to predict the steam properties of a coal-fired boiler lignite type.

Better thermal efficiencies can be achieved by a combination boiler, the components of which can be disassembled into three parts. The multipurpose boiler, in turn, allows the generation of hot water, steam, and thermal oil, being able to achieve the combustion of LPG.

To understand the research, the following sections as materials and methods are explained the plate thickness calculation, the material selection, the boiler construction process sequence, and the energy characterization using liquid petroleum gas (LPG). The hypotheses formulated were:

Hypothesis (H1). By sizing and constructing a vertical mixed boiler (pyro-water tube) multipurpose of 03 steps will optimize thermal efficiency with alternative fuels.

Hypothesis (H2). By constructing a vertical mixed multipurpose boiler with 03 steps, the limitation in using and exploiting the heat transfer fluid using alternative fuels will be solved. 


\section{Materials and Methods}

The materials used for the construction of the boiler are of three types:

(1) For the construction of the water and steam chamber, carbon steel ASTM 285-C was used, and for the tubes, ASTM 192 established by the ASME Code

(2) As an insulation material, super quality powder insulation and high-density mineral wool mat were used $[14,15]$.

(3) Galvanized metal sheet was used as the exterior coating [16,17]

(4) The exterior painting was done with anticorrosive paint and finishing paint [18]

\subsection{Plate Thickness Calculation and Material Selection}

According to the boiler's scheme, we calculate the plate thicknesses for which the ASME code is applied. The calculation procedure was executed by sections and location of the cylindrical thicknesses; the values to be applied in the case of vessels under internal pressure are calculated with the following expression, according to the initial parameters: $[19,20]$ :

$$
\begin{aligned}
& \text { Design Pressure }(\mathrm{Pd}) 150 \text { psig }=1 \mathrm{MPa} \\
& \text { Yield stress }(\mathrm{S})=13,800 \mathrm{psig}=93.8 \mathrm{MPa}
\end{aligned}
$$

Welded joint efficiency $=0.7$ (for untested joints)

$$
\begin{aligned}
R & =\text { Cylinder radius } \\
t & =\text { Plate thickness. }
\end{aligned}
$$

The formula for containers under internal pressure is:

$$
t=P \times R / S E-0.6 P
$$

The formula for vessels subjected to external pressure is:

$$
P a=4 \times B / 3(D o / t)
$$

where $B=$ a coefficient obtained from graphs, $C=$ outside diameter, $t=$ plate thickness and $L=$ length.

For elliptical caps submitted to Pi, the following formula was used:

$$
T=\frac{P * D}{2 S E-0.2 P}
$$

where $S=$ permissible material stress $(93.8 \mathrm{MPa}), E=$ welded joint efficiency (0.7), $D=$ diameter of the vessel and $P=$ upper vessel internal pressure (150 psi $<>1 \mathrm{MP})$.

The accuracy of the instruments used are:

- To measure the pressure, a manometer with a range of 0-200 psi approx. One psi.

- Contact thermometers with an approximation of 0.1 degrees to measure external surfaces

- $\quad$ Carbon steel plate, ASTM285 grade C in different thicknesses

- $\quad$ Seamless boiler tubes ASTM-192 seamless carbon steel boilers tubes

Table 3 shows the distribution of losses and thermal efficiencies of the alternative fuels to corroborate the above hypotheses. 
Table 3. Distribution of losses and thermal efficiencies (for hypotheses).

\begin{tabular}{ccccccc}
\hline \multirow{2}{*}{ Heat Loss \% } & \multicolumn{2}{c}{ Diesel } & \multicolumn{2}{c}{ Natural Gas } & \multicolumn{2}{c}{ LPG } \\
\cline { 2 - 7 } & $\begin{array}{c}\text { Heat } \\
\text { Water }\end{array}$ & $\begin{array}{c}\text { Heat } \\
\text { Steam }\end{array}$ & $\begin{array}{c}\text { Heat } \\
\text { Water }\end{array}$ & $\begin{array}{c}\text { Heat } \\
\text { Steam }\end{array}$ & $\begin{array}{c}\text { Heat } \\
\text { Water }\end{array}$ & $\begin{array}{c}\text { Heat } \\
\text { Steam }\end{array}$ \\
\hline Sensible Heat in Dry Gases \% & 7.45 & 7.28 & 6.10 & 6.10 & 5.25 & 5.19 \\
Enthalpy of water vapor in gases \% & 1.46 & 1.46 & 2.18 & 2.189 & 1.52 & 1.51 \\
Unburned Gaseous\% & 0.86 & 0.86 & 0.80 & 0.80 & 0.19 & 0.23 \\
Unburned Solid\% & 0.60 & 0.40 & 0.29 & 0.29 & 0.29 & 0.24 \\
By convection\% & 0.166 & 0.195 & 0.135 & 0.135 & 0.123 & 0.123 \\
By radiation\% & 0.255 & 0.29 & 0.24 & 0.24 & 0.23 & 0.23 \\
Resulting thermal efficiency\% & 89.21 & 89.31 & 90.25 & 90.24 & 92.4 & 92.42 \\
\hline
\end{tabular}

\subsection{Boiler Construction Process Sequence}

The construction process begins with the proper selection of the appropriate material, considering the calculations and results of the previous section as follows:

- $\quad$ Material type: Carbon steel plate ASTM 285 C

- Thickness: $1 / 4^{\prime \prime}$ or $6.53 \mathrm{~mm}$

- Plate dimensions: Depending on the dimensions required by the different sizes for its construction, it is possible to select larger plate dimensions

- $\quad$ Boiler tubes: For small powers, the manufacturers and the ASME Code recommend 2" diameter.

For the established area of heat transfer, the line was made in iron, taking into consideration that it must comply with making the economy of the cost of the material and the least amount of wasted material, in the same way, to reduce the cost of the services such as the rolling and the pumping of the steam chamber.

It is important to note that the combustion chamber and the liquid storage section called the water-vapor chamber were built separately and subsequently assembled [21].

The procedure to achieve the objective was as follows:

(1) Distribution of the transfer area in three gas passes.

(2) Calculation of the total volume of liquid to be stored

(3) Dimensioning of the plates whose thickness was previously calculated.

(4) Tracing, cutting, rolling, and welding of the various sections of the boiler.

(5) Determination of the type of assembly of the sections previously built

(6) Selection of the seal gaskets.

(7) Assembly of the pre-fabricated sections through connecting flanges.

(8) Tightness test called a hydrostatic test.

(9) Installation of thermal insulation.

(10) External covering with galvanized iron plate.

(11) Painting.

\subsection{Energy Characterization}

This section deals with the calculation of the thermal efficiency of the boiler. It is necessary to specify that two types of methods are known for the determination of the thermal efficiency as they are [13]:

(1) Direct

(2) Indirect.

The direct method considers the entry and use of heat so that ASME calculates the thermal efficiency $[3,22,23]$.

The direct method considers the entry and use of heat so that the thermal efficiency is calculated by:

$$
\eta=\frac{Q_{a}}{Q_{c}} * 100
$$


$Q_{a}=$ Heat absorbed

$Q_{c}=$ Heat of combustion

The indirect method considers the income and heat loss so that the thermal efficiency is calculated by:

$$
\eta=1-\frac{Q_{p}}{Q_{c}} * 100
$$

$Q_{p}=$ Lost heat

The heat input and utilization correspond to the absorbed and lost combustion heat.

The lost heat is equal to the sum of the residual heat contained in the combustion gases and the heat transferred to the environment through the walls of the boiler, can be broken down into six forms of lost heat $\left(Q p_{i}\right)$ corresponding to:

Qp1 = heat lost in the exhaust gases

$Q \mathrm{p} 2=$ heat lost by the enthalpy of water vapor in the gases

Qp3 = heat lost to unburned gas

Qp4 = heat lost by solid unburned

Qp5 $=$ heat lost by convection

Qp6 = heat lost to radiation

These lost heats are calculated as a percentage so that the efficiency is calculated as:

$$
\eta=100-\sum_{1}^{6} P i
$$

For the calculation of the thermal efficiency by the method of losses, a technical norm called NORMA TECNICA PERUANA NPT 350.300 the year 2002 was used [1].

Based on this method, efficiency calculations were made for three types of fuel: Diesel oil 2, natural gas, and liquid petroleum gas [24].

The thermal fluid to be used is water, which will work as liquid initially, and it is heated up to $99^{\circ} \mathrm{C}$ according to the ASME Code and then will work as saturated steam at a pressure of up to 10 psig to evaluate the thermal efficiency for both cases.

To carry out the temperature measurement according to the technical standard, the measurement of temperatures is carried out considering distributed average values according to what is indicated in Figure 4 below. As well as the wind speeds near the boiler [25-27].

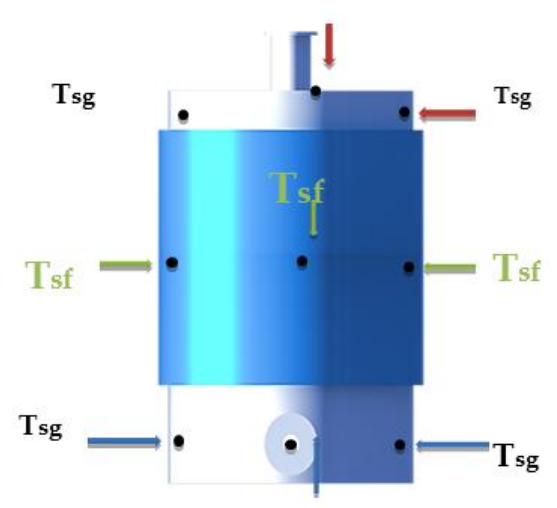

Figure 4. Temperature measuring points according to standard.

It is important to specify that the temperatures measured were carried out in the combustion chamber area as shown in Figure 4, in the sector on the gas outlet, and the boiler's side surfaces [28-30], and it is also proposed in Figure 5. 


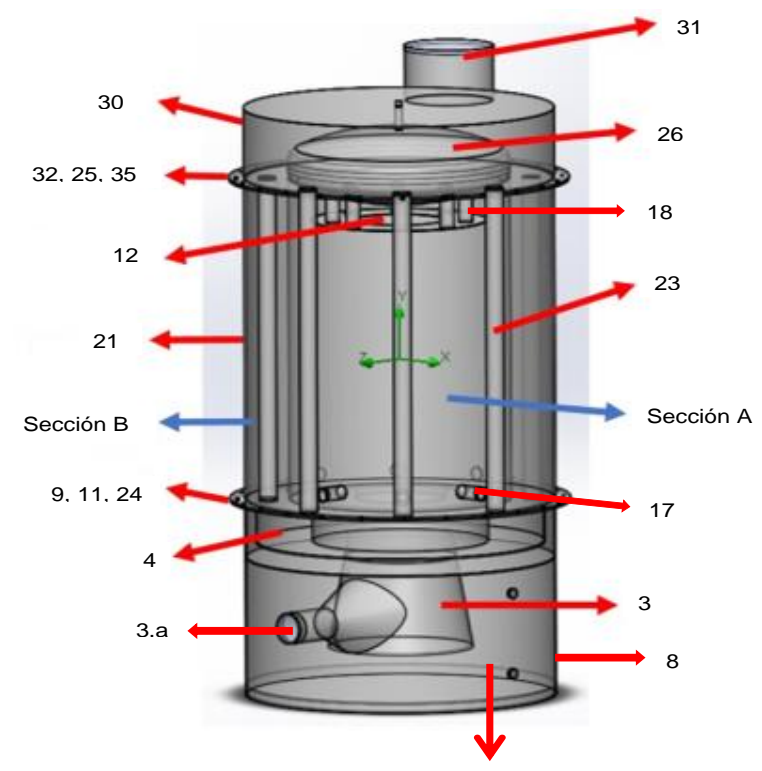

Figure 5. The vertical multipurpose three-pass pyro-water-tube boiler with alternative fuels. According to the previous figures, the device comprises: (3) Ignition enclosure; (3.a) Circular income; (4) Circular channel; (8) Sheet metal outer circular base vertical cylinder; (9) Upper circular combustion chamber support flange; (11) Tape packing; (12) Cylindrical hearth; (17) Plurality of radial tubes; (18) Short length vertical pipes; (21) Exterior vertical cylinder of metallic plate, conforms section B; (23) Vertical steel tubes; (24) Lower circular flange for water chamber support; 25) Upper circular flange to support the water chamber; (26) Dome; (31) Circular section of the chimney; (32) Round flange of the dome cover; (35) Circular sealing gasket between the flanges of the dome cover and the upper flange of the water chamber.

The formulas used in the calculation procedure, developed in the technical standard, were repeated for the fuels used and the thermal fluids tested. This article will show the calculation procedure carried out with LPG; also, the Myer Kutz. heat-transfer calculation formulas from were used $[1,25,29,30]$

Calculation formulas used for energy characterization:

$$
\eta=100-\left(P_{1}+P_{2}+P_{3}+P_{4}+P_{5}+P_{6}\right)
$$

Sensitive heat loss in dry gas: $P_{1}(\%$ de $\mathrm{kJ})$ Heats expressed in $\%$ :

$$
\begin{gathered}
P_{1}=k \frac{T_{g}-T_{a}}{\left[\mathrm{CO}_{2}\right]} \\
k=\text { Siegert's constant }^{\text {Sis }}
\end{gathered}
$$

Loss of water vapor enthalpy in gases: $P_{2}(\mathrm{~kJ})$ :

$$
P_{2}=\left[\left(H_{2} \mathrm{O}\right)+9(H)\right] *\left(210-4.2 * T_{a}+2.1 * T_{g}\right) / P C S
$$

The loss to unburned gas: $P_{3}(\mathrm{~kJ})$ :

$$
P_{3}=k_{1} \frac{[\mathrm{CO}]}{\left[\mathrm{CO}_{2}\right]+[\mathrm{CO}]}
$$

where $k_{1}=$ CHeat constant lost by unburned gaseous

Loss from solid unburned: $P_{4}(\mathrm{~kJ})$ :

$$
P_{4}=0.14 B^{2}+0.08 B+0.07
$$


where $\{B=2$ Bacharach Index $\}$

Convection losses: $P_{5}(\mathrm{~kJ})$ :

$$
\begin{gathered}
P_{5}=\frac{80 * Q_{P 5}}{W_{C}} \\
Q_{p 5}=h_{c f} A_{f}\left(T_{s f}-T_{a}\right)+h_{c g} A_{g}\left(T_{s g}-T_{a}\right)
\end{gathered}
$$

Calculation of the coefficients:

$$
\begin{gathered}
h_{c f}=1.973 * 10^{-3} \\
h_{c g}=1.973 * 10^{-3} \\
\dot{W} c=981 * B H P
\end{gathered}
$$

Radiation loss: $P_{6}(\mathrm{~kJ})$ :

$$
\begin{gathered}
P_{6}=\frac{80 * Q_{p 6}}{W_{c}} \\
Q_{P 6}=\left(q_{r f} * A_{f}\right)^{+}+\left(q_{r g} * A_{g}\right) \\
\left.q_{r f}=5.763 * 10^{-11} * \varepsilon *\right] \\
\varepsilon=\text { Surface emissivity } \\
q_{r g}=5.763 * 10^{-11} * \mathcal{E} * \\
\dot{W}_{c}=981 * B H P
\end{gathered}
$$

Efficiency:

$$
\eta=100-\sum P i
$$

\subsection{Energy Characterization Using Liquid Petroleum Gas (LPG)}

To heat water up to $99^{\circ} \mathrm{C}$

With the following input data, for calculation according to the Technical Standard, for the fuel used

$$
\begin{gathered}
T_{0}=22{ }^{\circ} \mathrm{C} \% \mathrm{Co}_{2}=12.4 \\
T_{\text {INITIAL }}=22{ }^{\circ} \mathrm{C} \% \mathrm{Co}=0.05 \\
T_{\text {END }}=99{ }^{\circ} \mathrm{C} \% \mathrm{O}_{2}=2.39 \\
T_{\text {fluegas }}=185^{\circ} \mathrm{C} \% N_{2}=85.16
\end{gathered}
$$

Efficiency:

$$
\begin{gathered}
\eta=100-\sum p i \\
\sum P i=5.25+1.52+0.19+0.29+0.123+0.23 \\
\sum P i=7.6 \\
\eta=100-7.6 \\
\eta=92.4 \%
\end{gathered}
$$

To generate steam

Considering pressure $=10 \mathrm{psig}$ and the calculation formulas used in the Technical Standard for the fuel used with the following input data:

$$
\begin{gathered}
T_{a}=22{ }^{\circ} \mathrm{C} \% \mathrm{CO}_{2}=12.4 \\
T_{\text {initial }}=22{ }^{\circ} \mathrm{C} \% \mathrm{CO}=0.06 \\
P_{\text {end }}=10 P S I \% \mathrm{O}_{2}=2.40 \\
T_{\text {gaseschimenea }}=183{ }^{\circ} \mathrm{C} \mathrm{N}_{2}=85.14
\end{gathered}
$$




$$
\begin{aligned}
& \text { Efficiency }=(\eta)=100-\sum P i \\
& \qquad \begin{array}{c}
\sum P i=5.19+1.51+0.23+0.29+0.123+0.23 \\
\sum P i=7.57 \\
\eta=100-7.57 \\
\eta=92.4 \%
\end{array}
\end{aligned}
$$

\section{Results}

With the calculations obtained from the distribution of losses and thermal efficiencies, shown in Table 4, the Sankey diagrams were elaborated to graph the distribution of losses for heating water and the distribution of losses to generate steam, represented in Figures 6 and 7.

Table 4. Distribution of losses and thermal efficiencies.

\begin{tabular}{ccc}
\hline \multirow{2}{*}{ Heat Loss \%. } & \multicolumn{2}{c}{ Fuel: LPG } \\
\cline { 2 - 3 } & Heat Water & Generate Steam \\
\hline Sensitive heat in the & 5.25 & 5.19 \\
Dry Gases \%. & 1.52 & 1.51 \\
Enthalpy of the steam of & 0.19 & 0.23 \\
Water in gases & 0.29 & 0.24 \\
\%Burned & 0.123 & 0.123 \\
Gaseous \%. & 0.23 & 0.23 \\
& Thermal Efficiency & \\
\% Resulting & 92.4 & 92.42 \\
\hline
\end{tabular}

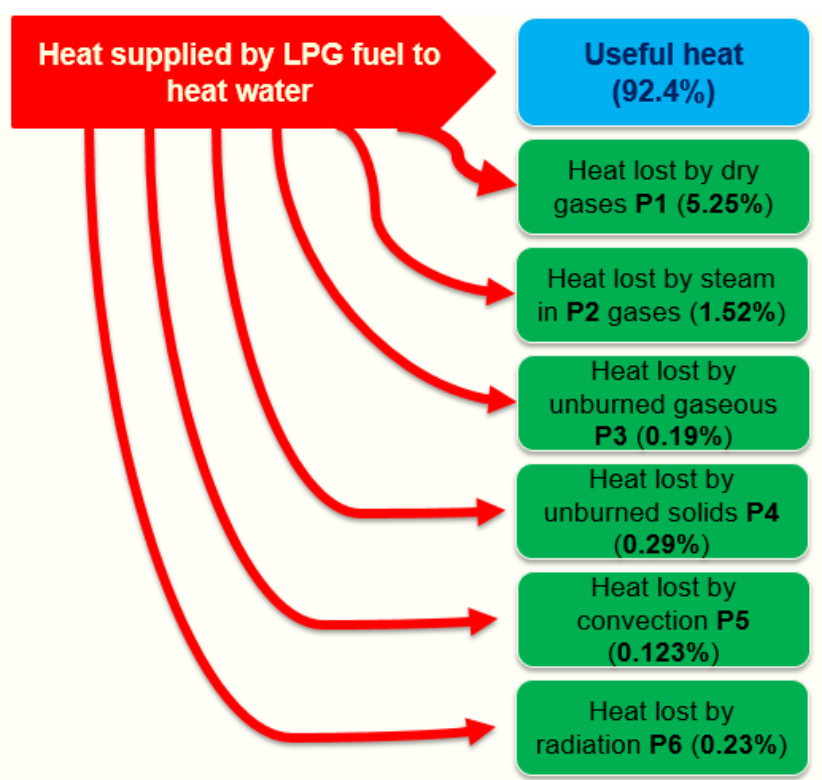

Figure 6. Sankey diagram: distribution of losses for heating water. 


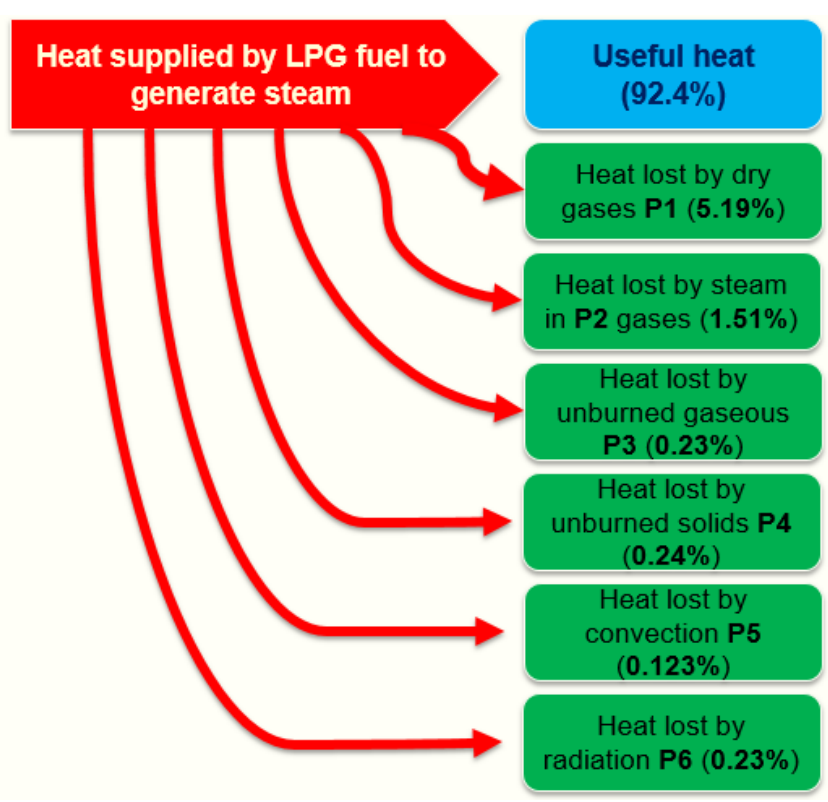

Figure 7. Sankey diagram: distribution of losses to generate steam.

Considering the sale prices of fuels, the specific costs were established that shows the fuel per power cost as in Table 5, unifying the comparison factor in $\mathrm{kg}$ of fuel consumed and the market value in US $\$$, for each fuel type. fuel and by the power the following: exchange rate $S / .3 .35$ / US $\$$.

Table 5. Comparison of specific fuel costs $(\mathrm{kg})$ per power.

\begin{tabular}{ccccc}
\hline & \multicolumn{2}{c}{ Heat Water } & \multicolumn{2}{c}{ Generate Steam } \\
\cline { 2 - 5 } & US\$ /BHP & US\$/kW & US\$ /BHP & US\$/kW \\
\hline Diésel & 0.59 & 0.06 & 1.39 & 0.14 \\
Natural gas & 0.24 & 0.024 & 0.51 & 0.052 \\
LPG & 0.36 & 0.037 & 0.77 & 0.079 \\
\hline
\end{tabular}

\section{Discussion}

The boiler of vertical construction, mixed (fire tube - water tube), consists of three passes of gases separated into three complementary subsystems for easy building and maintenance.

The mixed boiler (pyro-tubular) as a new design results in the optimization of its thermal efficiency for the fuels used and is in correlation with the modification made by the research formulated in [10] where modifications to the design of a water tube boiler achieving $90 \%$ thermal efficiency are implemented. According to [6], efficiencies close to $92 \%$ are achieved in the water tube boilers of a coal fired power plant, which shows that it is possible to make modifications to reach a new design [10,11,26].

When building a new type of boiler due to its mixed configuration and three gas passes with an equivalent heat transfer area concerning the one and two pass boilers, the intensity in the use of the combustion heat is immediately reflected in a higher level of use of the combustion heat and as a consequence a lower emission temperature of combustion gases to the environment $[6,16,25]$.

For the calculation of thermal efficiencies was used the indirect method resulting in the use of LPG are reached the highest values concerning natural gas and diesel 2, as shown in Table 3 loss distribution. It is possible to specify that using a Technical Standard and reliable measuring devices is necessary to achieve results that reflect greater reliability $[12,27]$.

The construction of an innovative prototype allowed overcoming the limitation of technological alternatives that can be used in the industrial sector in small service compa- 
nies or others, offering an economy of space and less investment by reducing the number of units according to the process used according to their needs $[19,28-30]$.

The mixed boiler (pyro-water tube) as a new design results in the optimization of its thermal efficiency for the fuels used and is in correlation with the modification made by the research formulated by Wejkowski [10], in which he implements modifications to the design of a water tube boiler achieving 90\% thermal efficiency. Strusnik et al. [6], in their research" Artificial Neural Networking Model for de Prediction of Higher Efficiency Boiler Steam Generation and Distribution," achieve efficiencies close to $92 \%$ in the water-tube boilers of a coal-fired thermal power plant, which shows that it is possible to carry out modifications to achieve a new design.

\section{Conclusions}

The construction of the vertical mixed boiler allowed the optimization of the thermal efficiency level achieving very significant thermal efficiency results: With LPG 92.4\% for hot water and $92.42 \%$ to generate steam in the same way with natural gas $90.25 \%$ for hot water and $90.24 \%$ to generate steam also with Diesel 2; $89.21 \%$ for hot water and $89.31 \%$ to generate steam.

The vertical mixed boiler allowed to solve the existing limitation as far as the production of the thermal fluid carrier of the heat and of space that is obtained with the option of multipurpose since it allows to produce hot water or water steam according to the requirement and in the same way it will enable the use of alternative fuels like Diesel, LPG and natural gas.

By building a new type of boiler for its vertical configuration, mixed and three passes of gases with a heat transfer area equivalent to the boilers of one and two steps, for the same boiler capacity, the level of utilization of the combustion heat is higher and therefore optimized the level of thermal efficiency as demonstrated.

The type of vertical boilers is limited to one or two gas passages due to the absence of technological alternatives; that could provide a vertical mixed boiler with three gas passages that simultaneously are accord to the environment, preserving the greenhouse effect. The low value of the temperatures emitted to the environment demonstrates a higher level of combustion heat and better economic resource use.

The technological research work has as the main innovative contribution the development, construction, and demonstration of a prototype of a vertical mixed boiler with three steps that can be separated into two subsystems, whose thermal efficiency can still be improved.

The consequences found are the lower temperature of gases emitted into the environment; it is a new type of boiler because it is an invention since it is multipurpose, offers space savings, and has better thermal efficiency values. The factors that affect the results are the lack of fuel or fluids that can transport heat, such as heat carriers, excess pressure due to lack of maintenance. The limitations found are the lack of precision in the instruments that could affect the results and the deficiency in their construction due to neglect in the joints' assembly.

Author Contributions: This study was designed, directed, and coordinated by D.A.V. as the principal investigator; D.A.V., D.E. and C.R. provided conceptual and technical guidance for all aspects of the research. D.E. and C.R planned and performed the methodology and analyzed the data with D.A.V., D.E. and C.R. performed and analyzed the optimal performance of the boiler experiments design and construction. C.R. contributed with the analytical algorithms, simulating with software. D.A.V., D.E. and C.R. performed and analyzed the data. D.A.V. and C.R. contributed to the technological innovation of vertical mixed fire tube and water tube boiler with three gas passes. D.E. contributed writing-original draft preparation, C.R writing-review, and editing, D.A.V. contributed with visualization, supervision of the project. D.A.V., D.E. and C.R. contributed to financing the research. The manuscript was written by C.R. and commented on by all authors. All authors have read and agreed to the published version of the manuscript.

Funding: This research received no external funding. Own authors resources financed the research. 
Acknowledgments: We would like to express our special thanks and gratitude to the colleagues who gave us the golden opportunity to do this wonderful project on the topic of the vertical boiler with three gas passes, which also helped us in doing a lot of group research on universities as UNI, UNFV, and UNMSM and we came to know about so many new things that we thankful to them.

Conflicts of Interest: The authors declare no conflict of interest.

\section{References}

1. INDECOPI. Norma Técnica Peruana NPT 350.300:2002 “CALDERAS INDUSTRIALES”. Procedimiento para la Determinación de la Eficiencia Térmica de Calderas Industriales; Lima, Peru.1a edición 15 de diciembre del 2002. Lima, Peru, 2020. Available online: http:/ / www.minem.gob.pe/_detalle.php?idSector=12\&idTitular=3094\&idMenu=sub3006\&idCateg=742 (accessed on 16 September 2020).

2. Dolmos, M.; Esenarro, D.; Rodriguez, C.; Minga, C. Wind Energy Potential in Pillcomarca, Peru, 2020. In Proceedings of the 5th Asia Conference on Power and Electrical Engineering (ACPEE), Chengdu, China, 4-7 June 2020; pp. 284-288. [CrossRef]

3. Boiler, A.S.M.E. ASME Boiler and Pressure Vessel Code and International Code Rules for Construction of Heating Boiler; 10016-5990; ASME: New York, NY, USA, 2005.

4. Babcock, W.B. Steam, Its Generation and Use, 13th ed.; Standardsmedia: London, UK, 2005.

5. Douglas, M.C. Tendencias de las Tecnologías Energéticas; University of Toronto: Toronto, ON, Canada, 1989; pp. 21-24.

6. Strusnik, D.; Golob, M.; Avsec, J. Artificial neural networking model for the prediction of high efficiency boiler steam generation and distribution. Simul. Modell. Pract. Theory 2016, 57, 58-70. [CrossRef]

7. Megyesy, E.F. Manual de Recipientes a Presión, Diseño y Calculo; Editorial LIMUSA: Mexico City, Mexico, 1998.

8. Moring, F.V.; Max, S.C. Termodinámica; UTEHA: Mexico City, Mexico, 1993.

9. Ganapathy, V. Waste Heat Boiler. Desk Book; The Fairmont Inc. Press: Liburn, GA, USA, 1991.

10. Wejkowski, R. Triple-finned tubes - Increasing efficiency, decreasing $\mathrm{CO}_{2}$ pollution of a steam boiler. Energy 2016, 99, 304-314. [CrossRef]

11. Rodriguez, C.; Sifuentes, M.; Kaseng, F.; Lezama, P. Algorithmic efficiency indicator for the optimization of route size. 3C Tecnología 2020. [CrossRef]

12. Pandey, B.; Tomar, G.; Singh, B.R.; Rodriguez, C. Environment-friendly FSM design on ultra-scale architecture: Energy-efficient green computing approach. World J. Eng. 2020. [CrossRef]

13. Fernández, G. Monographic Study on Technologies of Medium Voltage Electric Generators in Wind Turbines; Paper Presented to Opt for the Title of University Expert in Wind Energy; National University of Distance Education: Madrid, Spain, 2012; Available online: http:/ / bit.ly /2cRTrNJ (accessed on 23 February 2021).

14. Esenarro, D.; Escate, V.; Anco, I.; Tassara, C.; Rodriguez, C. Proposal for an Ecological Research Center for the Recovery and Revaluation of Biodiversity in the Town of Quichas-Lima, Peru. Int. J. Environ. Sci. Dev. 2020, 11, 212-216. [CrossRef]

15. Rodriguez, C.; Esenarro, D.; Alburquerque, C.; Vega, M.; Ramirez, V. Theme park of renewable energies for mitigation of $\mathrm{CO}_{2}$ in the urban area of the district of Chorrillos, Peru. IOP Conf. Ser. Mater. Sci. Eng. 2020, 910, 012021. [CrossRef]

16. Wrobel, W.A.; Fornalik-Wajs, E.; Szmyd, J.S. Analysis of the influence of a strong magnetic field gradient on convection process of paramagnetic fluid in the annulus between horizontal concentric cylinders. J. Phys. Conf. Ser. 2012, 395, 012124. [CrossRef]

17. Kenjereš, S.; Fornalik-Wajs, E.; Wrobel, W.; Szmyd, J.S. Inversion of flow and heat transfer of the paramagnetic fluid in a di_erentially heated cube. Int. J. Heat Mass Transf. 2020, 151, 119407. [CrossRef]

18. Fornalik-Wajs, E.; Roszko, A.; Donizak, J.; Kraszewska, A. Comparison of the experimental and numerical analyses of silver nanofluid under influence of strong magnetic field. Int. J. Numer. Methods Heat Fluid Flow 2019, 30, 3139-3162. [CrossRef]

19. Fornalik-Wajs, E.; Roszko, A.; Donizak, J. Nanofluid flow driven by thermal and magnetic forces-Experimental and numerical studies. Energy 2020, 201, 117658. [CrossRef]

20. Kraszewska, A.; Pyrda, L.; Donizak, J. Experimental analysis of the enclosure aspect ratio influences thermo-magnetic convection heat transfer. J. Phys. Conf. Ser. 2016, 745, 032153. [CrossRef]

21. Zhang, D.; Peng, H.; Ling, X. Lattice Boltzmann method for thermomagnetic convection and entropy generation of paramagnetic fluid in porous enclosure under magnetic quadrupole field. Int. J. HeatMass Transf. 2018, 127, 224-236. [CrossRef]

22. Furuichi, Y.; Tagawa, T. Numerical study of the magnetic damping e_ect on the sloshing of liquid oxygen in a propellant tank. Fluids 2020, 5, 88. [CrossRef]

23. He, W.; Qin, G.; Wen, X.; Lin, J.; Jia, C. Resonant enhancement of thermomagnetic convection of paramagnetic fluid in an enclosure due to time-periodic magnetizing force. Numer. Heat Transf. Part A Appl. 2020, 78, 1-17. [CrossRef]

24. Bahiraei, M.; Hangi, M. Automatic cooling by means of thermomagnetic phenomenon of magnetic nanofluid in a toroidal loop. Appl. Therm. Eng. 2016, 107, 700-708. [CrossRef]

25. Ozoe, H. Magnetothermal wind tunnel. In Magnetic Convection, 1st ed.; Imperial College Press: London, UK, 2005; pp. 193-204. ISBN 10: 1-86094-578-3.

26. Pleskacz, L.; Fornalik-Wajs, E. Low Reynolds number flow's heat transfer influenced by strong magnetic field. J. Phys. Conf. Ser. 2016, 745, 032156. [CrossRef]

27. Pleskacz, Ł.; Fornalik-Wajs, E. Identification of the structures for low Reynolds number flow in the strong magnetic field. Fluids 2019, 4, 36. [CrossRef] 
28. Wada, K.; Kaneda, M.; Suga, K. Rayleigh-Bénard convection of paramagnetic liquid under a magnetic field from permanent magnets. Symmetry 2020, 12, 341. [CrossRef]

29. Kaneda, M.; Fujiwara, H.; Wada, K.; Suga, K. Natural convection of paramagnetic fluid along a vertical heated wall under a magnetic field from a single permanent magnet. J. Magn. Magn. Mater. 2020, 502, 166574. [CrossRef]

30. Kutz, M. Heat-Transfer Calculations; McGraw-Hill Education: New York, NY, USA, 2006; Available online: https://www. accessengineeringlibrary.com/content/book/9780071410410 (accessed on 23 February 2021). 